\title{
Physicochemical Properties and Nutritional Evaluation of Jackfruits (Artocarpus Heterophyllus L.)
}

\author{
Seleim M.A.A and Manal.A.M.Hassan* \\ Food Science and Technology Department, Faculty of Agriculture, Assiut University, Assiut 71526, Egypt
}

\begin{abstract}
Jackfruits are very versatile in their uses for food and as a folk medicine. Most parts of the jackfruit including pulp and seeds are edible. Three cultivars jackfruit (Artocarpus heterophyllus Lam.) namely: SS1, SS2 and SS3 which cultivated in Aswan, Egypt, were studied for their physical properties, minerals, chemical composition, polyphenolic compounds, ascorbic acid, alpha tocopherol and beta carotene contents. Also, jams were prepared from mango pulp and jack fruit pulp, as well as, sensory evaluation, chemical composition and storage for six months for these jams was determined. The results revealed that TSS (\%), TTA (\% DW) contents ranged from 24.21-26.23 and 0.37-0.46; respectively. The non-reducing sugars, reducing sugars were found in studied pulps with higher contents ranging 30.64-33.75\%and20.57-22.14\%; respectively, while the total sugars ranged between 52.78 to $54.32 \%$. The concentration of potassium was significantly $(\mathrm{P}<0.05)$ higher $(1928.84)$ in SS3 followed by SS2 (1899.82) and SS1 (1897.66). The vitamin C content (mg/100g DW) in three strains of jackfruit pulp was ranged from 30.44 to 30.66 . Jackfruit pulps contained reasonable amounts of anioxidative components especially vitamin A and polyphenolics. The jam made from jackfruit pulp and mango pulp with ratio 1:1 give a better acceptable product with good properties, it had the highest in total, reducing sugars with values 89.63 and $26.89 \mathrm{~g} / 100 \mathrm{~g}$ DW, respectively. The T.S.S and T.T.A were slightly increased during 6 months with no significance differences between jackfruit and mango jams. There is a decrease in total and non-reducing contents during storage but reducing sugars was increased in jam samples. The results showed that consumption of jackfruit can enhance the amounts of phytochemical compounds such as vitamins A and $\mathrm{C}$ consumed. In addition, the importance of this study is to prepare jackfruit jam that will be characteristically accepted by consumer.
\end{abstract}

Keywords: Polyphenolic compounds, Vitamin A, Mango jam, Jackfruits

\section{INTRODUCTION}

The jackfruit (Artocarpus heterophyllus Lam.) is traditionally a tropical fruit used as a nation medicine for the treatment of tapeworm infection, malarial fever, diabetes, diarrhea and other ailments as well as for food. The Artocarpus species were found mostly in South-East Asia, particularly in Philippines, India, Thailand, Indonesia and Malaysia.

Based on their plant structure, $8-15 \%$ of the fruit mass is represented by seeds surrounded by brown spermoderm which it covers the white cotyledon that is high in starch and protein. The fruit of most jackfruit cultivars weights $10-30 \mathrm{~kg}$, although the full range of known cultivars is $2-36 \mathrm{~kg}$ and even heavier. Based on fruit quality, the fruit is mostly divided into two main varieties the first one have strong smell soft very sweet pulp with thin fibrous texture and the second is thick, firm, often crisp, less fragrant pulp (Prakash et al., 2009; Dasaesamoh and Seechamnanturakit 2014).

The jackfruit was consists of about $54 \%$ crust $29 \%$ pulp and $12 \%$ seed. The inner part of the ripe fruit has a large sweet, tasty yellow bulb, clustered between narrow strips and a central pity heart consisting of 25-30\% of the total fruit. Edible bulbs of mature grapefruit are consumed for their wonderful taste and enjoyable smell, which it contain high levels of thiamine, calcium starch and protein. It is also rich in energy, dietary fiber, minerals and vitamin (Eke-Ejiofor et al., 2014).

Fresh fruits are a good source of iron, magnesium, potassium and manganese, as well as contain small amounts of flavonoids and vitamin A which these compounds play vital, an important role in vision and as antioxidants. The composition (wet weight) of Jack fruit pulp contained average total solids $23.69 \%$, acidity $0.25 \%$, total sugar $17.78 \%$, protein $1.75 \%$, ash $0.93 \%$ and fat $0.22 \%$. Depending on high nutritive value of jackfruit pulp it eaten as fresh and used in fruit salads. The mature pulp of jackfruit $(100 \mathrm{~g})$ contains moisture $77 \%$, carbohydrate $18.9 \mathrm{~g}$, protein $1.9 \mathrm{~g}$, fiber 1.1 $\mathrm{g}$, fat $0.1 \mathrm{~g}$, ash $0.8 \mathrm{~g}$, potassium 191 to $407 \mathrm{mg}$, phosphorus 38 to $41 \mathrm{mg}$, calcium 20 to $37 \mathrm{mg}$, iron 0.50 to $1.70 \mathrm{mg}$, vitamin A 175 to 540 I.U and vitamin C 12 to $14 \mathrm{mg}$ with a caloric value of 84 calories (Mondal et al., 2013; Jagdeesh et al., 2007; Naik et al., 2017). 
Fruits contain vitamin A precursor beta-carotene which converted to vitamin A easily. Vitamin A deficiency reduces the body's resistance to infection. In developing countries, carotenoids (pro-vitamin) in fruits and vegetables are the main source of vitamin A for 70-90\% of people. Among carotenoids, lycopene, lutein and beta-carotene are the highest in antioxidant properties (Umesh et al., 2010, Swami et al., 2012).

\section{Jack fruit storage}

Generally, In order to extend the shelf life of fruits and vegetables it's processed into jellies, juices, jams or pickles. The enzymes classes of hydrolases (amylase, invertase, cellulose, lipase, tannase, chlorophylase) and oxidoreductases (ascorbinase, polyphenoloxidase, catalase, peroxidase, tyrosinase) are played an important role in fruit storage which caused spoilage together with microorganisms. So, the industrial and thermal processes of the fruit to food products like jam caused destroying of microorganisms and inhibit the enzymes activity which leads to the product stability during storage (Eke-Ejiofor and Owuno 2013, Mondal et al., 2013).

The aim of this investigation was to determine some physical characteristics, the gross chemical composition, total phenolics, flavonoids, vitamins (A, C, E) and minerals content of three cultivars of jackfruit (SS1, SS2, SS3). In addition, processing of jackfruit jams from the best sample in maturity, taste index (SS3) comparing with mango jam, as well as, gross chemical composition, sensory evaluation and effect of storage in the refrigerator on the resulted products were also determined.

\section{MATERIALS AND METHODS}

Materials: The studied fruits used in this investigation were selected seed strains of breeding program to improve the pomological characteristics of these jack-fruit fruits, namely SS1, SS2 and SS3 for the golden black cultivar, which purchased from the Tropical Farm at Agricultural Research Station - Kom Ombo - Aswan Governorate - Upper Egypt during season 2018.

Jack fruit pulp preparation; The fruit pulp was collected from the seeds and dried under vacuum at $50{ }^{\circ} \mathrm{C}$ for 24 hours. The dried pulp was grinded in a laboratory mill to obtain complete flour from it, then stored at $4^{\circ} \mathrm{C}$ until analyzed.

\section{Methods}

Proximate composition analysis

Physical properties

pH value, T.S.S (total soluble solids) and T.T.A (total titratable acidity) contents were determined as described by A.O.A.C (2000) methods.

\section{Taste index and the Maturity}

A taste index and the maturity were calculated using the equation proposed by Navez et al., (1999) and Nielsen (2003) as follow:

Taste index $=[($ Brix degree $) /(20 \times$ Acidity $)]+$ Acidity.$\quad$ The maturity $=$ Brix degree/ Acidity .

Chemical composition: Moisture, ash, crude oil, crude protein, total sugars, non-reducing sugars and reducing sugars were determined as described in the AOAC Methods (2000).

Minerals content: Contents of $\mathrm{Ca}, \mathrm{Mg}, \mathrm{Fe}, \mathrm{Zn}, \mathrm{Cu}, \mathrm{Mn}, \mathrm{Se}, \mathrm{Ni}, \mathrm{Cr}, \mathrm{Pb}, \mathrm{As}$ and $\mathrm{Cd}$ in the studied samples were determined by iCAP6200 (ICP-OES) Inductively Coupled Plasma Emission Spectrometry (Isaac and Johnson. 1985). A flame photometer corning 400 was used to determine $\mathrm{Na}$ and $\mathrm{K}$; while, spectrophotometer was used for determination of $\mathrm{P}$ content (Jackson, 1967) after wet ashing as recording in AOAC (2000).

Polyphenolic compounds: The total, bound and free phenolic compounds contents of samples were determined using modified Folin-Ciocâlteu colorimetric method (Singleton et al., 1999).

Ascorbic acid content: The method described by Sahlin et al., (2004) was used for ascorbic acid determination. The results were calculated as $\mathrm{mg} / 100 \mathrm{~g}$ dry weight (DW).

\section{$\beta$ - Carotene determination by HPLC}

The method of Tee and Lim (1991) was used for $\beta$-carotene determination. The studied sample (5g) was hydrolyzed with $5 \mathrm{ml}$ of $100 \% \mathrm{KOH}$ and $20 \mathrm{ml}$ of $95 \%(\mathrm{v} / \mathrm{v})$ ethanol (HPLC grade) then refluxed for $30 \mathrm{~min}$. The $\mathrm{n}$-hexane was used to extraction of hydrolysate and then passed through anhydrous sodium sulphate for drying purposes. The extraction was repeated three times. Extracted samples were then filtered through $0.45 \mu \mathrm{m}$ nylon membrane 


\section{International Advanced Research Journal in Science, Engineering and Technology}

Vol. 6, Issue 10, October 2019

(Whatman, Maidstone, England) filter and analysed using a reversed phase HPLC using $\mu$ Banda Pak C18 (3.9 x 300 $\mathrm{mm})$ column and acetonitrile-methanol-ethyl acetate $(88: 10: 2)$ as the mobile phase. The eluted $\beta$-carotene eluted was detected and quantified using a UV-Visible detector attached to the 600 controller model (Waters, Milford, MA, USA) HPLC. The peak areas of appropriate standard ( $\beta$-carotene) and retention time (rt) was used to identify and quantify the isolated $\beta$-carotene.

\section{$\alpha$ - Tocopherol determination by HPLC}

The studied sample $(2 \mathrm{~g})$ was weighted into centrifuge tubes, then $1 \mathrm{ml}$ of distilled water, $1 \mathrm{ml}$ of methyl tert-butyl ether (MtBE), $1 \mathrm{ml}$ of ethanol, and $1 \mathrm{ml}$ of petroleum ether were added. The tubes were shaken for 30 seconds after each addition. Then, the samples tubes were centrifuged $(5000 \mathrm{rpm}, 5 \mathrm{~min})$, the upper layer was taken and put into a flask. The extraction was repeated twice with $1 \mathrm{ml}$ of petroleum ether and $1 \mathrm{ml}$ of MtBE. The combined extracts were concentrated under vacuum at $30^{\circ} \mathrm{C}$ in a rotary evaporator. The residue was solved in $2 \mathrm{ml}$ of mobile phase ( $n$-hexane: MtBE; 96: 4, v/v) and then centrifuged (5 min, $14000 \mathrm{rpm}$ ). The produced solution was analyzed for vitamin E by HPLC at $50^{\circ} \mathrm{C}$. Tocopherols are separated on a column packed with $5 \mu \mathrm{mLiChrosorb}$ RP18 (Merck) (120 x4.6 mm), with water/methanol (2/98) as the mobile phase, flow rate: $1.5 \mathrm{~mL} / \mathrm{min}$ (Balz et al., 1992).

\section{Jam from jack fruit pulp and mango pulp preparation}

Jam was prepared according to the traditional method using mango fruit pulp and jack fruit pulp (SS3 strain based on taste index, maturity) as a raw materials (Table 1).

Table (1): Formulation of mango and jack fruit gam.

\begin{tabular}{|l|c|c|c|}
\hline Ingredients $(\mathrm{g})$ & Control & $\mathrm{A}^{*}$ & $\mathrm{~B}^{* *}$ \\
\hline Mango pulp & 1000 & 500 & --- \\
\hline Jack fruit pulp & --- & 500 & 1000 \\
\hline Sugar & 1000 & 1000 & 1000 \\
\hline Citric acid & 3 & 3 & 3 \\
\hline
\end{tabular}

$* \mathrm{~A}=$ Jack fruit jam made with $50 \%$ mango pulp. $* * \mathrm{~B}=$ Jack fruit jam made with $100 \%$ jack fruit pulp.

The fruits were washed, peeled and cut into small pieces of similar size. Then, the prepared fruit pulp and a little of sugar was placed in a cooker and blended well. The blend was cooked under constant stirring for 12-15 minutes during which the remaining sugar and citric acid was added. Then the mixture was cooked until the T.S.S reached $68^{\circ}$ Brix. After that, the heat was turned off and the Jam was cooled to $87^{\circ} \mathrm{C}$, filled in sterilized (autoclaved at $121^{\circ} \mathrm{C}$ for 15 min) glass dry jars.

\section{Storage of jackfruit and mango jam}

The studied jam were stored at refrigerator temperature $\left(8 \pm 1^{\circ} \mathrm{C}\right)$ for six months at one month interval to determine physico-chemical properties: $\mathrm{pH}$, TSS, TTA, TSS/TTA ratio, total sugars, reducing sugars, non-reducing sugars and vitamin $\mathrm{C}$ according to their own methods as previously mentioned.

\section{Sensory evaluation of jam}

Jam products were sensory evaluated by a panel of the judges from the staff of Food science and Technology department, Faculty of Agriculture, Assiut University. International protocols (ISO 6658: 2005) were used to perform the descriptive analyses. The parameters estimated using ten points hedonic scales were: consistency (10), intensity of odour (10), homogeneity in colour (10), intensity of taste (10), free of sugar granules (10) \& overall acceptability (10).

\section{Statistical analysis:}

All data were subjected to statistical analysis using package of SAS. Mean comparisons were done using LSD 5\% (SAS 2000).

\section{RESULTS AND DISCUSSION}

\section{Physical properties of Jackfruit cultivars}

The Jackfruit cultivars genotypes were analyzed for physical properties (Table 1). There are significant $(\mathrm{P}<0.05)$ differences among the seeds strains of jackfruit in most physical characteristics which ranged $4.01-5.34 \mathrm{~kg}, 1.96-2.74 \mathrm{~kg}$, $1.40-1.79 \mathrm{~kg}, 0.81-0.87 \mathrm{~kg}$ for fruit, pulp, peel and seed weights; respectively. As illustrated in Table (1) the physical properties of jackfruit pulp are different which SS3 have highest contents for maturity (65.43) and taste index (3.64) comparing to the others. TSS (\%), TTA (\% DW) contents ranged from 24.21-26.23 and 0.37-0.46, respectively. These differences in physical properties content both whole fruits or fruit pulp could be mainly due to the properties of strains in the climate of the place where the plant, maturity, soil type and fertility (Mondal et al., 2013 Naik et al., 2017). 


\section{International Advanced Research Journal in Science, Engineering and Technology}

Vol. 6, Issue 10, October 2019

Table (1): Physical chracteristics of three cultivars of jack fruits

\begin{tabular}{|l|c|c|c|c|}
\hline \multirow{2}{*}{ Analysis } & \multicolumn{3}{|c|}{ Samples } & \multirow{2}{*}{ LSD 0.05 } \\
\cline { 2 - 4 } & SS1 & SS2 & SS3 & \\
\hline Fruit weight (kg) & 4.31 & 4.01 & 5.34 & 0.12 \\
\hline Pulp weight (kg) & 2.04 & 1.96 & 2.74 & 0.10 \\
\hline Peel weight (kg) & 1.40 & 1.49 & 1.79 & 0.21 \\
\hline Seed weight (kg) & 0.87 & 0.56 & 0.81 & 0.09 \\
\hline Pulp percentage (\%) & 47.33 & 48.88 & 51.31 & 0.24 \\
\hline Peel percentage (\%) & 32.48 & 37.16 & 33.52 & 0.10 \\
\hline Seed percentage (\%) & 20.19 & 13.96 & 15.17 & 0.18 \\
\hline T.S.S & 25.79 & 26.23 & 24.21 & 0.16 \\
\hline T.T.A (DW) & 0.46 & 0.41 & 0.37 & 0.13 \\
\hline Maturity & 56.07 & 63.98 & 65.43 & 0.21 \\
\hline Taste index & 3.26 & 3.61 & 3.64 & 0.12 \\
\hline
\end{tabular}

Chemical composition of jack fruit pulp samples

The gross chemical composition of SS1, SS2 and SS3 jackfruit pulp are shown in Table (2). The obtained data indicated significantly $(\mathrm{P}<0.05)$ that the moisture content was 78.21, 77.51, 77.88\% for SS1, SS2 and SS3; respectively. It could be observed that protein contents were 7.04, 7.37, 7.60\%, while the oil contents were 1.07, 1.05, and $1.09 \%$ for SS1, SS2 and SS3; respectively. Ash, and crude fiber contents were 3.58, 4.01, 3.37\% and; 3.18, 3.14, $3.22 \%$ for the above-mentioned studied samples. The reducing sugars and non-reducing sugars were found in studied pulps with higher contents ranging $20.57-22.14 \%$ and $30.64-33.75 \%$; respectively. While the total sugars ranged between 52.78 to $54.32 \%$. These results are very similar to that reported previously (Jagdeesh et al., 2007; Naik et al., 2017).

Table (2): Chemical composition (g/100 g dry weight)* of jack fruit pulp samples.

\begin{tabular}{|l|c|c|c|c|c|c|c|c|}
\hline Samples & Moisture & Ash* & Oil* & Protein* & $\begin{array}{c}\text { Crude } \\
\text { fiber* }\end{array}$ & $\begin{array}{c}\text { Reducing } \\
\text { sugars* }\end{array}$ & $\begin{array}{c}\text { Non reducing } \\
\text { sugars* }\end{array}$ & $\begin{array}{c}\text { Total } \\
\text { sugars* }\end{array}$ \\
\hline SS1 & 78.21 & 3.58 & 1.07 & 7.04 & 3.18 & 20.57 & 33.75 & 54.32 \\
\hline SS2 & 77.51 & 4.01 & 1.05 & 7.37 & 3.14 & 21.16 & 32.74 & 53.90 \\
\hline SS3 & 77.88 & 3.37 & 1.09 & 7.60 & 3.22 & 22.14 & 30.64 & 52.78 \\
\hline LSD0.05 & 0.20 & 0.10 & 0.08 & 0.21 & 0.12 & 0.24 & 0.09 & 0.04 \\
\hline
\end{tabular}

\section{Mineral Composition}

The mineral composition (mg/100g dry weight) in studied Jackfruit pulp (Table 3) revealed that the concentration of potassium was significantly $(\mathrm{P}<0.05)$ higher $(1928.84)$ in SS3 followed by SS2 (1899.82) and SS1 (1897.66).

Table (3): Mineral composition (mg/100g dry weight) of jack fruit pulp samples.

\begin{tabular}{|l|c|c|c|c|}
\hline \multirow{2}{*}{ Analysis } & \multicolumn{3}{|c|}{ Samples } & LSD 0.05 \\
\cline { 2 - 4 } & SS1 & SS2 & SS3 & \\
\hline $\mathrm{K}$ & 1897.66 & 1899.82 & 1928.84 & 0.22 \\
\hline $\mathrm{Ca}$ & 134.44 & 139.42 & 141.22 & 0.26 \\
\hline $\mathrm{Mg}$ & 137.17 & 125.22 & 134.00 & 0.15 \\
\hline $\mathrm{P}$ & 164.13 & 172.24 & 162.45 & 0.10 \\
\hline $\mathrm{Fe}$ & 121.23 & 129.53 & 130.05 & 0.06 \\
\hline $\mathrm{Na}$ & 94.80 & 88.50 & 91.60 & 0.19 \\
\hline $\mathrm{Se}$ & 1.95 & 1.98 & 2.04 & 0.17 \\
\hline $\mathrm{Mn}$ & 0.98 & 0.88 & 0.92 & 0.07 \\
\hline $\mathrm{Zn}$ & 0.87 & 0.83 & 0.86 & 0.05 \\
\hline $\mathrm{Cu}$ & 0.79 & 0.78 & 0.82 & 0.07 \\
\hline $\mathrm{Cr}$ & 1.69 & 1.77 & 1.73 & 0.10 \\
\hline $\mathrm{Ni}$ & 0.72 & 0.72 & 0.71 & 0.05 \\
\hline $\mathrm{As}$ & 0.15 & 0.15 & 0.15 & 0.08 \\
\hline $\mathrm{Pb}$ & 0.078 & 0.082 & 0.079 & 0.006 \\
\hline $\mathrm{Cd}$ & 0.005 & 0.006 & 0.005 & 0.005 \\
\hline
\end{tabular}

There were significant $(\mathrm{P}<0.05)$ variations in contents of $\mathrm{Ca}, \mathrm{Mg}, \mathrm{P}, \mathrm{Fe}$ which ranged 134.44-141.22, 125.22-137.17, 162.45-172.24 and 121.23-130.05 mg/100g DW; respectively. In addition, the contents of Se, $\mathrm{Mn}, \mathrm{Zn}$ and $\mathrm{Cu}$ were in the same range with small values. As illustrated in Table (3) the contents of heavy metals in the studied samples was 


\title{
International Advanced Research Journal in Science, Engineering and Technology
}

\author{
Vol. 6, Issue 10, October 2019
}

found in small quantities, which $\mathrm{Cr}$, Ni ranged 1.69-1.77 and 0.71-0.72 mg/100g DW; respectively. The same way was found for $\mathrm{Cd}$ and $\mathrm{Pb}$ contents with no significant differences. Similar reports have been made by Manjeshwar $e t$ al., (2011); Swami et al., (2012) and Tang et al., (2013) in jackfruit pulp. The differences in mineral composition could be due to environmental conditions and varietal differences.

\section{Vitamins (C, A, E) and polyphenolic compounds composition of jackfruit pulp}

The contents of vitamins and polyphenolic compounds are presented in Table (4). The total polyphenolic compounds content (mg GAE/100g DW) was significantly higher ranging 1904.48-1992.45 as compared with bound (1845.33$1957.78)$ and free phenolic (34.67-64.95) for three pulps under study. The amount of vitamin $\mathrm{C}(\mathrm{mg} / 100 \mathrm{~g} \mathrm{DW}) \mathrm{in}$ three strains of jackfruit pulp was ranged from 30.44 to 30.66. From the biological view vitamins can be measured by international units (IU) which differed from vitamin to another. For example one IU of vitamins A, E under study equivalents of $0.6 \mathrm{mcg}$ beta-carotene and $0.67 \mathrm{mg}$ natural- $\alpha$-tocopherol, respectively, in addition IU was used with other substances having biological activity (Reinagel 2011).

The counted vitamins A, E as international units of jackfruit pulp cultivars from $\beta$-carotene and $\alpha$-tocopherol contents under study are presented in Table (4). The data recorded that vitamin A contents was significantly $(\mathrm{P}<0.05)$ higher and ranged from 362.82 to $374.28 \mathrm{IU}$ in the studied pulps. On the other hand, the vitamin E content was lower with ranging 1.07-1.11 IU for the same samples. From the results in Table (4) it is clear that jackfruit pulps contained reasonable amounts of anioxidative components especially vitamin A and polyphenolics, which confirmed the importance of these strains as a nutritional material having greater antioxidant activity in retarding oxidation during processing and storage periods. Also, it is believed to keep the body safe against degenerative disorders such as cardiovascular disease and cancer (Umesh et al., 2010, Swami et al., 2012).

Table (4): Vitamins (C, A, E) and polyphenolic compounds composition of pulp from three cultivars of jack fruits.

\begin{tabular}{|l|c|l|c|c|c|c|}
\hline Sample & $\begin{array}{c}\text { Vit. C (mg/100g } \\
\text { D.W) }\end{array}$ & \multirow{2}{*}{$\begin{array}{l}\text { Vitamin A } \\
\text { (IU) }\end{array}$} & \multirow{2}{*}{$\begin{array}{c}\text { Vitamin E } \\
(\mathbf{I U})^{\mathbf{b}}\end{array}$} & \multicolumn{3}{|c|}{$\begin{array}{c}\text { Polyphenolic compounds (mg } \\
\text { GAE/100g D.W) }\end{array}$} \\
\cline { 5 - 7 } & & & & Free & Bound & Total \\
\hline SS1 & 30.66 & 368.08 & 1.07 & 34.67 & 1957.78 & 1992.45 \\
\hline SS2 & 30.44 & 374.28 & 1.09 & 64.95 & 1845.33 & 1910.28 \\
\hline SS3 & 30.52 & 362.82 & 1.11 & 51.99 & 1852.49 & 1904.48 \\
\hline LSD 0.05 & 0.16 & 0.03 & 0.13 & 0.07 & 0.18 & 0.05 \\
\hline
\end{tabular}

a- One international Unit (IU) of vitamin $\mathrm{A}=0.6 \mathrm{mcg}$. of beta-carotene. b- One international Unit (IU) of vitamin $\mathrm{E}=$ $0.67 \mathrm{mg}$ natural alpha-tocopherol.

Sensory evaluation of mango and jackfruit pulp Jams

The results of sensory evaluation of studied jams were illustrated in Table (5). It is clear that the mango jam recorded the highest values in sensory attributes with total score 54.10 followed by the jam sample made with $50 \%$ jackfruit pulp scoring 51.35. The total score for $100 \%$ jackfruit pulp jam was lower than the other jam samples with value 47.50 . Make of jam from 100\% jackfruit pulp resulted product with less acceptability especially for coulor and odour comparing with the others, which the data showed some significant $(\mathrm{P}<0.05)$ differences in parameters among jams under study. Therefore, the jam made from mango and jackfruit pulps with ratio 1:1 give a better acceptable product with good properties comparing with jam made from jackfruit pulp only.

Table (5) Sensory Evaluation of mango and jack fruit (SS3 based on maturity and taste index) jam.

\begin{tabular}{|l|c|c|c|c|c|c|c|}
\hline Sample & $\begin{array}{c}\text { Consistency } \\
\mathbf{( 1 0 )}\end{array}$ & $\begin{array}{c}\text { Homogeneity } \\
\text { in colour } \\
\mathbf{( 1 0 )}\end{array}$ & $\begin{array}{c}\text { Intensity } \\
\text { of } \\
\text { odour(10) }\end{array}$ & $\begin{array}{c}\text { Intensity } \\
\text { of taste } \\
(\mathbf{1 0})\end{array}$ & $\begin{array}{c}\text { Free of } \\
\text { sugar } \\
\text { granules (10) }\end{array}$ & $\begin{array}{l}\text { Over all } \\
\text { acceptability } \\
(\mathbf{1 0})\end{array}$ & $\begin{array}{l}\text { Total } \\
\text { score } \\
(\mathbf{6 0})\end{array}$ \\
\hline Control & 9.00 & 9.15 & 8.80 & 9.15 & 9.00 & 9.00 & 54.10 \\
\hline A & 8.80 & 8.25 & 8.50 & 8.50 & 9.00 & 8.30 & 51.35 \\
\hline B & 8.00 & 7.50 & 7.50 & 8.00 & 9.00 & 7.50 & 47.50 \\
\hline LSD 0.05 & 0.89 & 0.08 & 0.19 & 0.70 & 0.90 & 0.18 & 0.21 \\
\hline
\end{tabular}

Control= Mango jam made with 100\% mango pulp. A = Jack fruit jam made with 50\% mango pulp. B = Jack fruit jam made with $100 \%$ jack fruit pulp.

\section{Chemical composition of mango and jack fruit jams}

Table 6 showed the chemical composition of jackfruit jams as compared with mango jam. The results showed that there are significant $(\mathrm{P}<0.05)$ variations between moisture content ranging 31.63-33.68\%. No significance was found among jams in protein, ash, and oil contents. The A (Jack fruit jam made with $50 \%$ mango pulp) jam was significantly $(\mathrm{P}<0.05)$ the highest in total, reducing sugars with values 89.63 and $26.89 \mathrm{~g} / 100 \mathrm{~g} \mathrm{DW}$, respectively, compared to other 
Vol. 6, Issue 10, October 2019

jams. The data about jam composition are in accordance with some previous studies in this field (Eke-Ejiofor and Owuno 2013, Mondal et al., 2013).

Table (6): Chemical composition (g/100 g dry weight)* of mango

and jack fruit (SS3 based on maturity and taste index) jam.

\begin{tabular}{|l|c|c|c|c|c|c|c|}
\hline Samples & Moisture & Ash* & Oil* & Protein* & $\begin{array}{l}\text { Reducing } \\
\text { sugars* }\end{array}$ & $\begin{array}{l}\text { Non reducing } \\
\text { sugars* }\end{array}$ & $\begin{array}{l}\text { Total } \\
\text { sugars* }\end{array}$ \\
\hline Control & 31.63 & 0.16 & 0.02 & 0.34 & 24.79 & 59.87 & 84.66 \\
\hline A & 33.02 & 0.29 & 0.02 & 0.40 & 26.89 & 62.74 & 89.63 \\
\hline B & 33.68 & 0.32 & 0.02 & 0.53 & 25.88 & 63.34 & 89.22 \\
\hline LSD0.05 & 0.09 & 0.10 & 0.06 & 0.08 & 0.04 & 0.07 & 0.03 \\
\hline
\end{tabular}

Control= Mango jam made with $100 \%$ mango pulp. A = Jack fruit jam made with $50 \%$ mango pulp. $\mathrm{B}=\mathrm{Jack}$ fruit jam made with $100 \%$ jack fruit pulp.

T.S.S, T.T.A, T.S.S/T.T.A ratio and pH of stored mango and jackfruit jams

The T.S.S, T.T.A, T.S.S/T.T.A ratio and $\mathrm{pH}$ of mango and jackfruit jams stored at refrigerator temperature $\left(8 \pm 1^{\circ} \mathrm{C}\right)$ are presented in Figures 2-5. The results revealed that the T.S.S (Fig. 2) and T.T.A (Fig. 3) were slightly increased during 6 months with no significance $(\mathrm{P}<0.05)$ differences among mango and jackfruit jams.

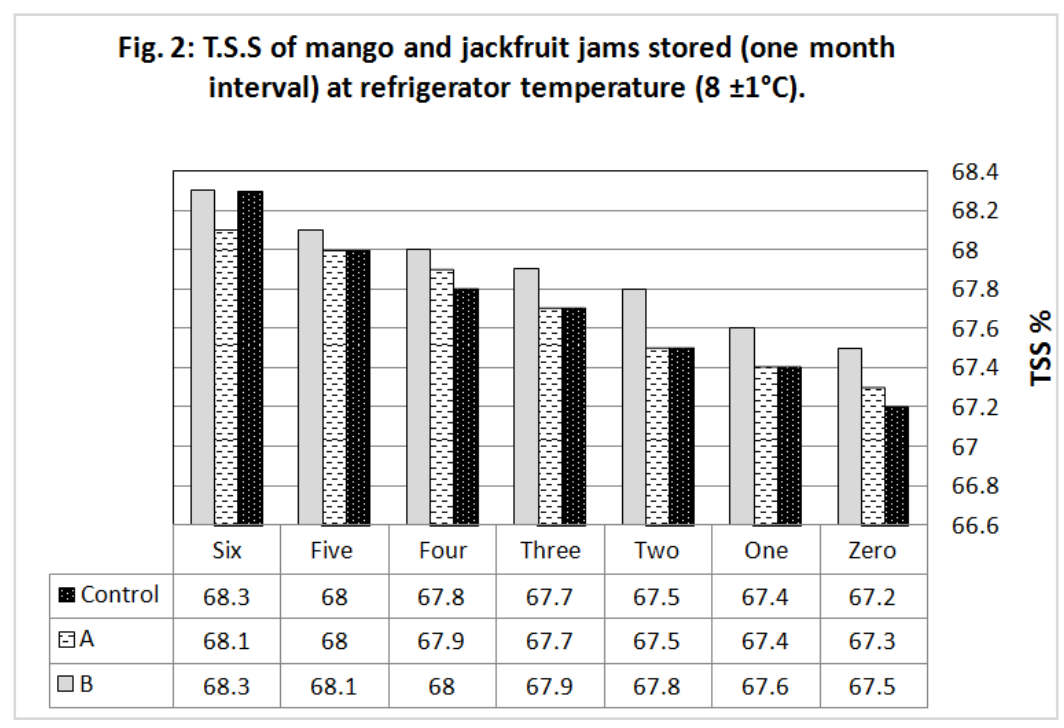

Fig. 3: T.T.A of mango and jackfruit jams stored (one month interval) at refrigerator temperature $\left(8 \pm 1^{\circ} \mathrm{C}\right)$.

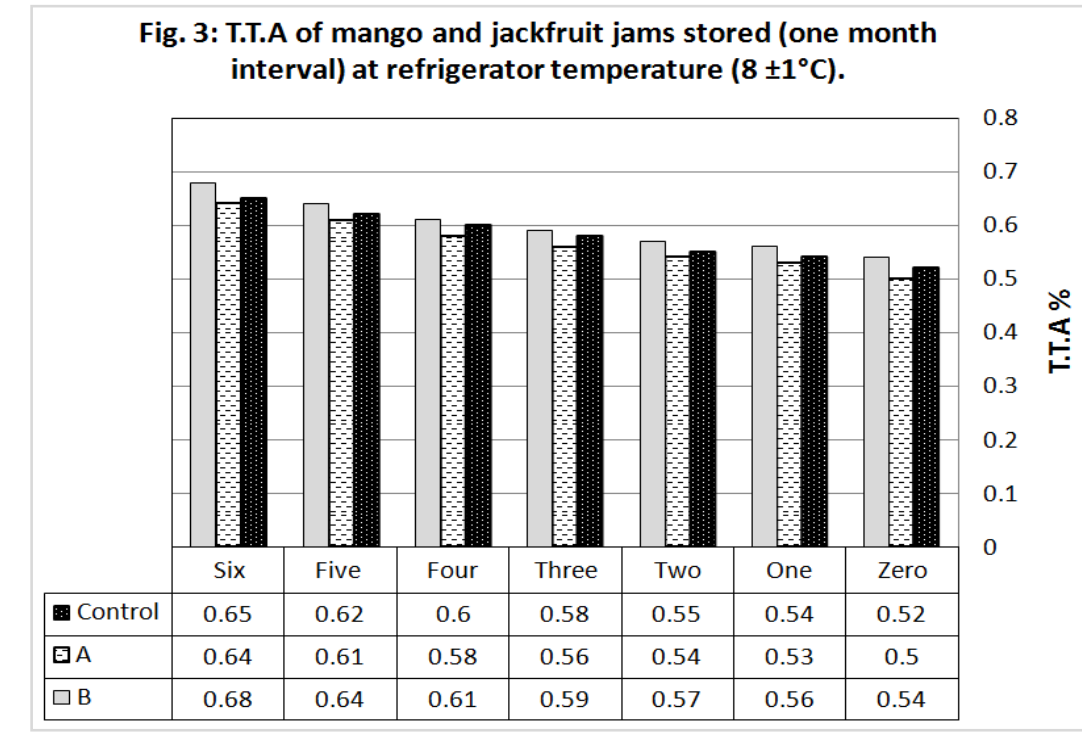

Control $=$ mango jam made with $100 \%$ mango pulp. $A=$ Jack fruit jam made with $50 \%$ mango pulp. $\mathrm{B}=\mathrm{Jack}$ fruit jam made with $100 \%$ jack fruit pulp. 
Vol. 6, Issue 10, October 2019

The T.S.S was ranged from 67.20 to $68.30 \%$ for the studied jams while; the T.T.A content of jams was increased from 0.50 to $0.68 \%$. The T.S.S/T.T.A (Fig. 4) ratio was decreased significantly $(\mathrm{P}<0.05)$ ranging $125.00-100.44$, this decrease depends on T.S.S and T.T.A values increment.

Consequently, the $\mathrm{pH}$ (Fig. 5) value was decreased as a result of T.T.A increment, which ranging 3.30-3.48. During storage some changes was done for example solubilization of jam contents, pectin hydrolysis, decomposition of ascorbic acid or increase in ionized weakly acid which caused the increased in T.S.S, T.T.A amounts and decreased in $\mathrm{pH}$. Our results on these properties are in agreement with some studies in this field (Hussain and Shakir 2010; Khan et al., 2012; Safdar et al., 2012) which confirmed the importance of acidity, sugars and the sugar/acid ratio in determine taste; give a technological properties of jams.

Fig. 4: T.S.S/T.T.A ratio of mango and jackfruit jams stored (one month interval) at refrigerator temperature $\left(8 \pm 1^{\circ} \mathrm{C}\right)$.

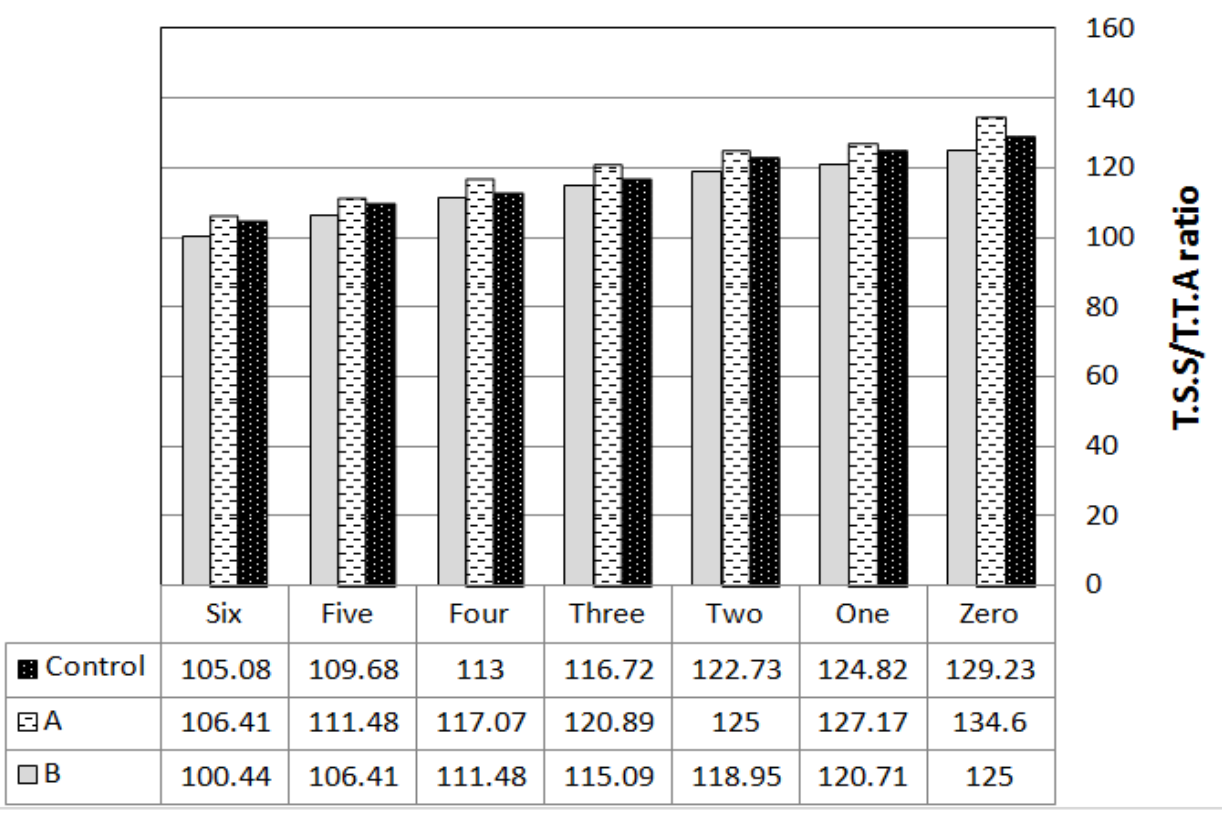

Fig. 5: pH of mango and jackfruit jams stored (one month interval) at refrigerator temperature $\left(8 \pm 1^{\circ} \mathrm{C}\right)$.

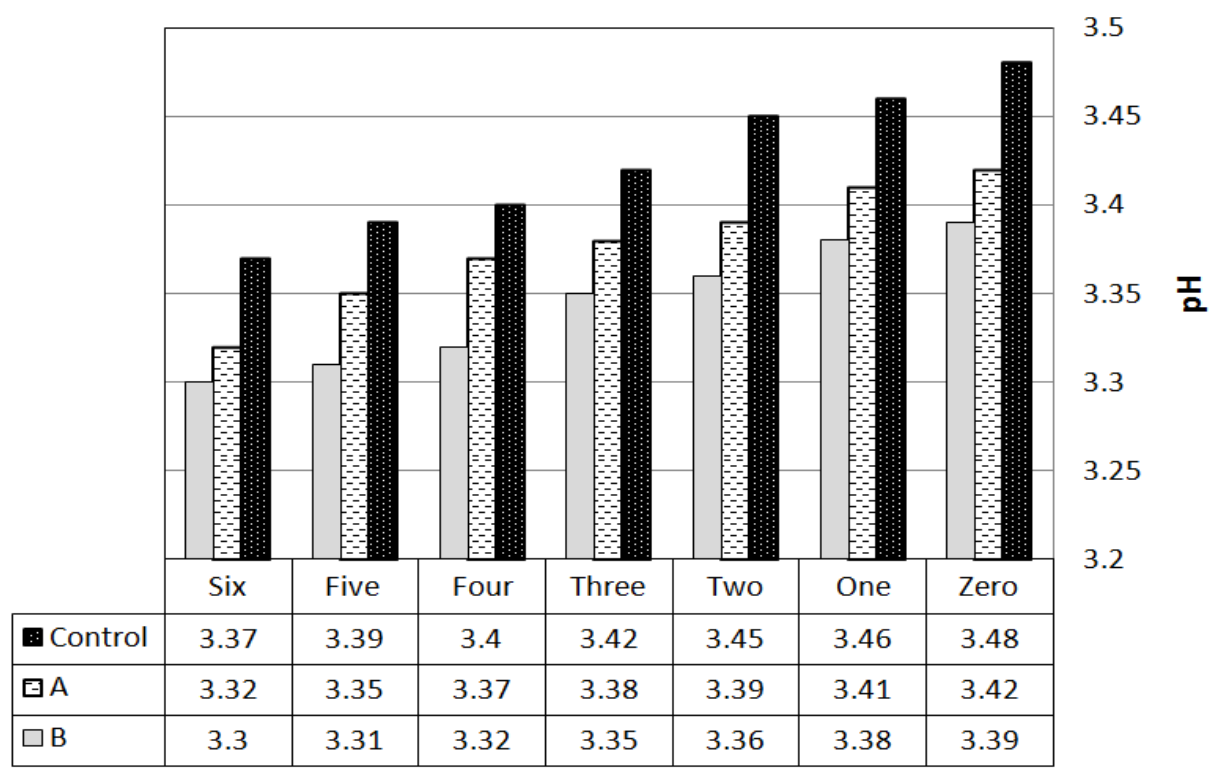

Control= mango jam made with $100 \%$ mango pulp. A = Jack fruit jam made with $50 \%$ mango pulp. $\mathrm{B}=\mathrm{Jack}$ fruit jam made with $100 \%$ jack fruit pulp. 
Vol. 6, Issue 10, October 2019

Total sugars, reducing sugars, non-reducing sugars, vitamin $\mathrm{C}$ contents of stored mango and jackfruit jams Total sugars, reducing sugars, non-reducing sugars, vitamin $\mathrm{C}$ contents (on dry weight basis) of mango and jackfruit jams stored at refrigerator temperature $\left(8 \pm 1^{\circ} \mathrm{C}\right)$ were illustrated in Figures 6-9.

\section{Fig. 6: Total sugars contents (g/100g D.W.) of mango and jackfruit jams stored (one month interval) at refrigerator temperature $\left(8 \pm 1^{\circ} \mathrm{C}\right)$.}

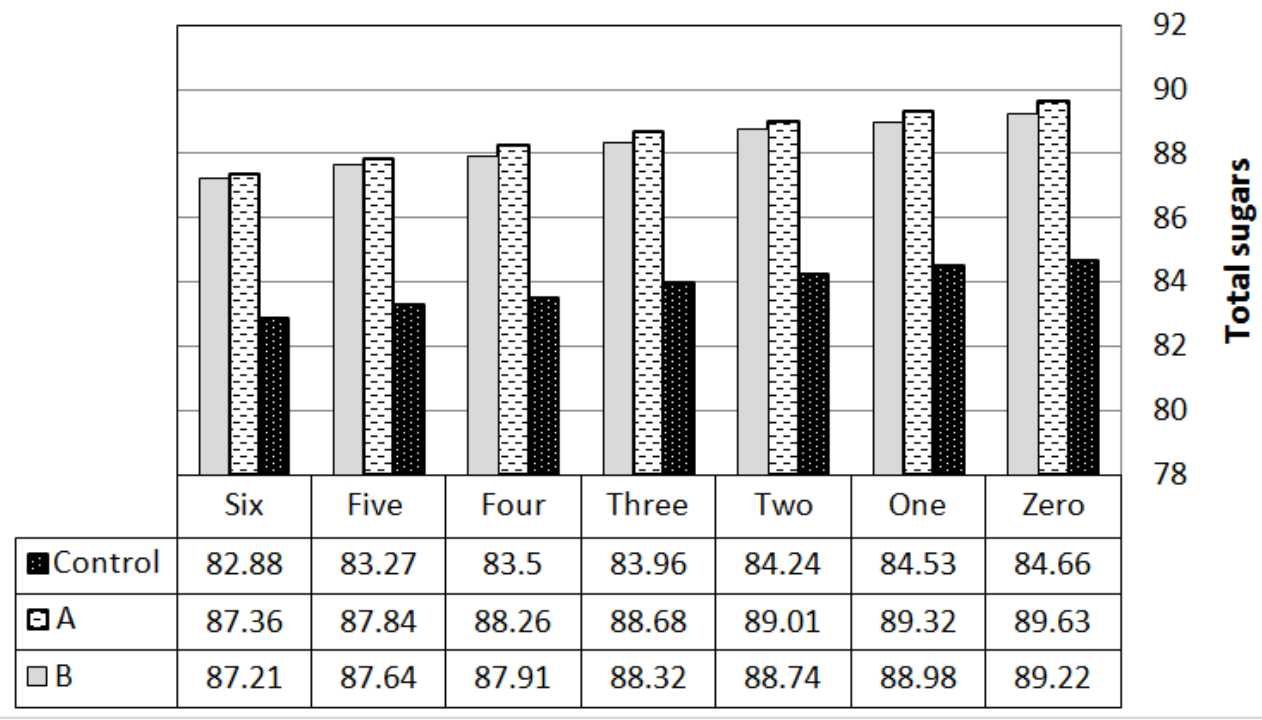

The data for sugars (Fig. 6, 7, 8) revealed significantly $(\mathrm{P}<0.05)$ that there is a decrease in total and non-reducing contents during storage but reducing sugars was increased in jam samples. As a result of non-reducing inversion which reproduces glucose, fructose, the reducing sugars content was increased with range24.79-28.74 mg glucose/100g DW. From Fig. 9 it could be noticed that vitamin $C$ was decreased significantly with range $3.61-5.54 \mathrm{mg} / 100 \mathrm{~g} D W$ in the studied jams during storage. This decrease was a result of oxidation of vitamin $\mathrm{C}$ to dehydroascorbic acid. On the other hand, during processing of Jam by traditional method the vitamin $\mathrm{C}$ content was decreased significantly compared with its content in fresh fruit. The above mentioned data were in accordance with previous studies (Damiani et al., 2012; Khan et al., 2012; Safdar et al., 2012).

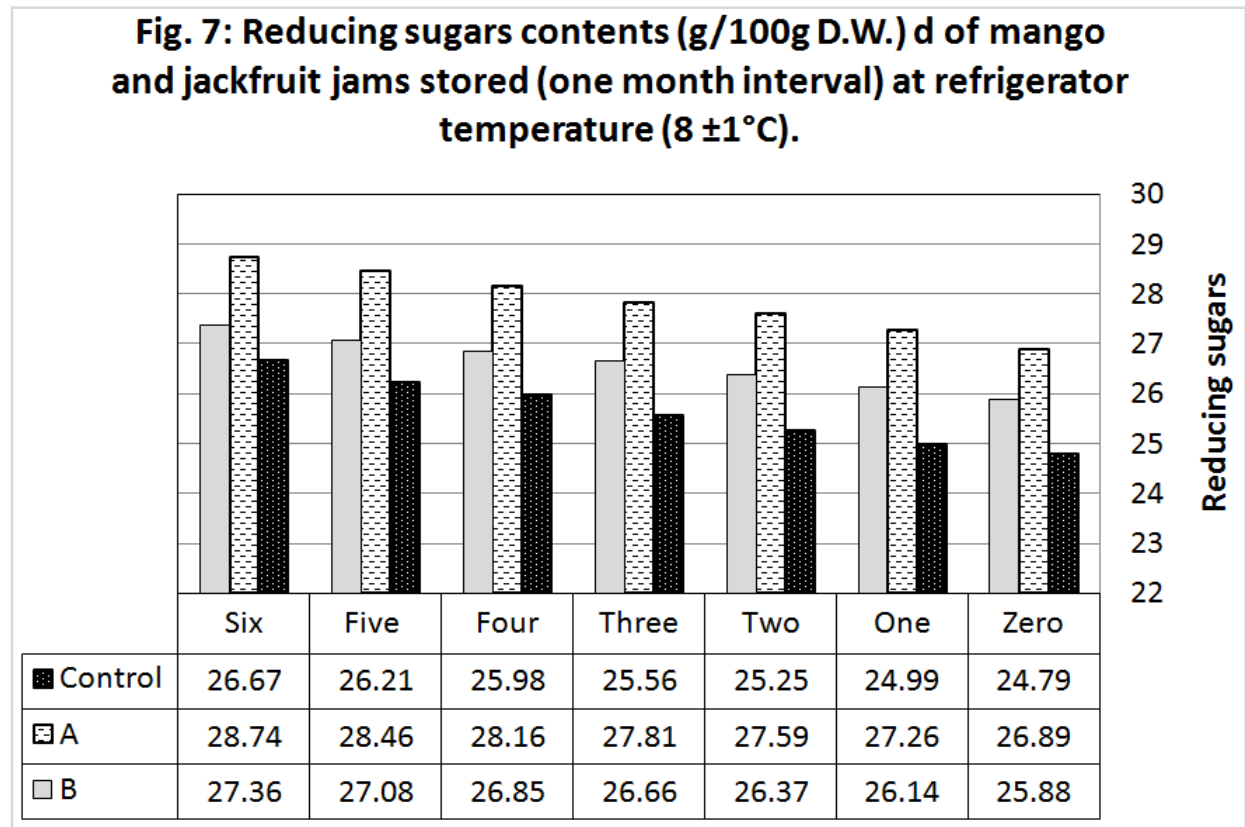

Control= mango jam made with $100 \%$ mango pulp. A = Jack fruit jam made with $50 \%$ mango pulp. $\mathrm{B}=\mathrm{Jack}$ fruit jam made with $100 \%$ jack fruit pulp. 

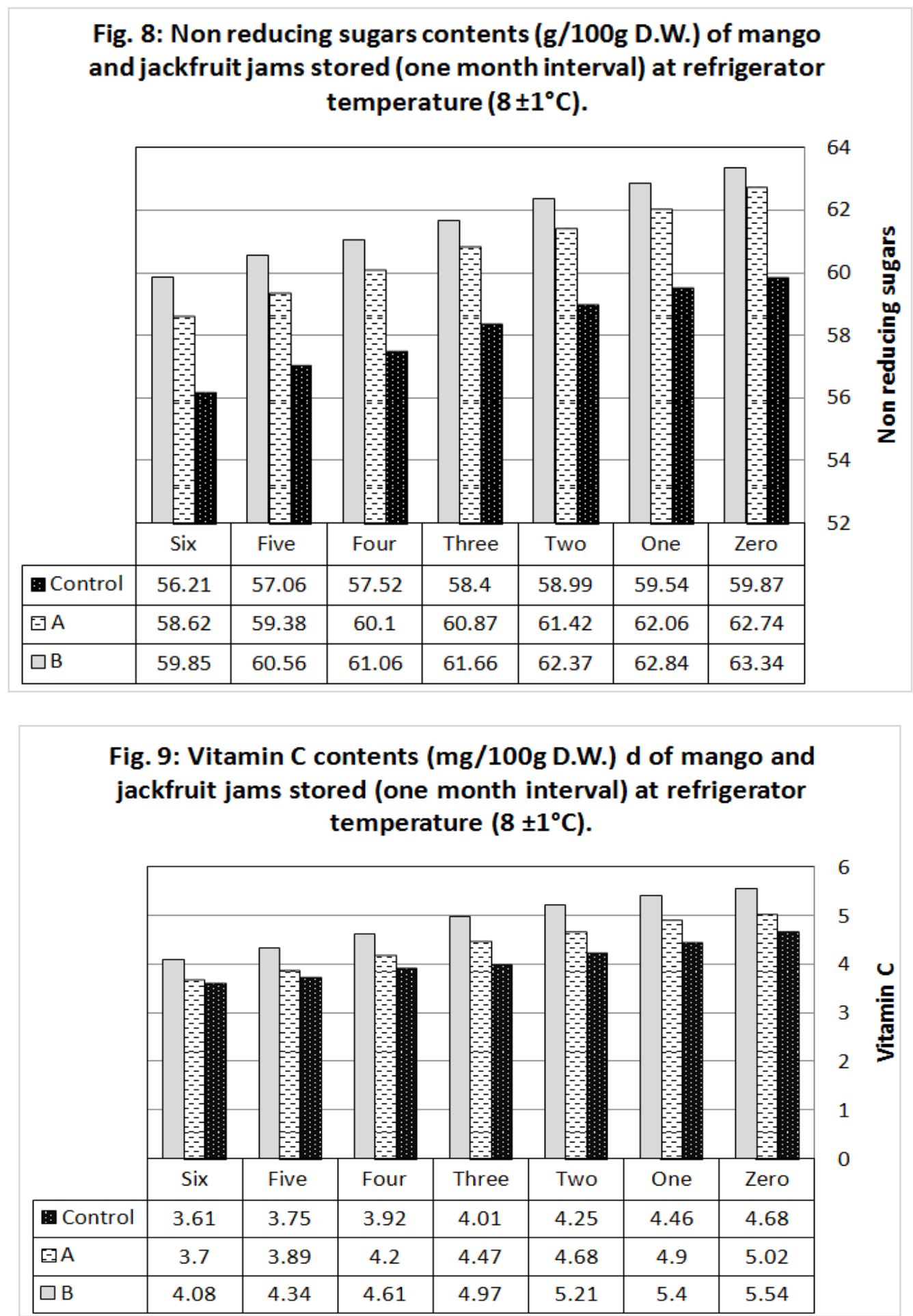

Control= mango jam made with $100 \%$ mango pulp. $\mathrm{A}=$ Jack fruit jam made with $50 \%$ mango pulp. $\mathrm{B}=\mathrm{Jack}$ fruit jam made with $100 \%$ jack fruit pulp.

\section{CONCLUSION}

The results of this study concluded that the seeds strains jackfruit cultivars contained high moisture and T.S.S contents. The physical properties of jackfruit pulp are different which SS3 have highest contents for maturity (65.43) and taste index (3.64) as compared to the others. The reducing sugars, non-reducing sugars were found in studied pulps with higher contents ranging 20.57-22.14\% and 30.64-33.75\%; respectively. While the total sugars ranged between 52.78 to $54.32 \%$. There were significant $(\mathrm{P}<0.05)$ differences in contents of $\mathrm{K}, \mathrm{Ca}, \mathrm{Mg}, \mathrm{P}$ and $\mathrm{Fe}$, this variation could be due to varietal differences and environmental conditions. The jackfruit pulps have reasonable amounts of anioxidative 


\title{
International Advanced Research Journal in Science, Engineering and Technology
}

\author{
Vol. 6, Issue 10, October 2019
}

components especially vitamin A and polyphenolics. The jam made from mango pulp and jackfruit pulp with ratio 1:1 gave a better acceptable product with good properties comparing with jam made from jackfruit pulp only. The T.T.A content of stored jams was increased from 0.50 to $0.68 \%$. Consequently, the $\mathrm{pH}$ value was decreased as a result of T.T.A increment, which ranging 3.30-3.48. There is a decrease in total and non-reducing contents during storage but reducing sugars was increased in jam samples. So, results confirmed the importance of these strains as a nutritional material having greater antioxidant activity in retarding oxidation during processing and storage periods.

\section{REFERENCES}

[1]. AOAC, Association of Official Analytical Chemists. Official Methods 965.33. Official Methods of Analysis, 17" Ed., Gaithersburg, MD, 2000.

[2]. M. Balz, E. Schulte and H. P. Thier, Trennung von Tocopherolen und Tocotrienolen durch HPLC. Fat Sci. Technol, 94 (6): 209-213, 1992.

[3]. C. Damiani, R.E. Asquieri, E.M. Lage, O.A. Rodrigo, S.A. Flavio, P.P.E. Douglas and B.V. Eduardo, Study of the shelf-life of a mixed araça (Psidium guineensis Sw.) and marolo (Annona crassiflora Mart.) jam. Ciênc. Tecnol. Aliment., Campinas, 32(2), pp. 334-343, 2012.

[4]. R. Dasaesamoh and V. Seechamnanturakit, Extraction and enzymatic depolymerization of gum from Artocarpus heterophyllus Lam. Seeds. International Food Research Journal 21(6): 2245-2251, 2014.

[5]. J. Eke-Ejiofor and F. Owuno, The Pysico-Chemical and Sensory Properties of Jackfruit (Artocarpus Heterophilus) Jam. International Journal of Nutrition and Food Sciences. 2: 149-152, 2013.

[6]. J. Eke-Ejiofor, E.A. Beleya and N.I. Onyenorah, The effect of processing methods on the functional and compositional properties of jackfruit seed flour. International Journal of Nutrition and Food Sciences, 3(3): 166-173, 2014

[7]. I. Hussain and I. Shakir, Chemical and organoleptic characteristics of jam prepared from indigenous verities of apricot and apple. World Journal of Dairy \& Food Sciences, 5 (1): 73-78, 2010.

[8]. R.A. Isaac and W.A. Johnson, 1985. Elemental Analysis of Plant Tissue by Plasma Emission Spectroscopy: Collaborative Study. Journal of Association of Official Analytical Chemists, 68: 499-505, 1985.

[9]. ISO 6658:(E), (the International Organization for Standardization), Sensory analysis Methodology General guidance. $2^{\text {nd }}$ ed, Switzerland, 2005.

[10]. M.L. Jackson, Soil Chemical Analysis. Printice-Hall of India. Private Limited, New Delhi, 1967.

[11]. S.L. Jagadeesh, B.S. Reddy, G.S.K. Swamy, K. Gorbal, L. Hegde and G.S.V. Raghavan, Chemical composition of jackfruit (Artocarpus heterophyllus Lam.) selections of Western Ghats of India. Food Chem., 102: 361-365, 2007.

[12]. U.R. Khan, R.S. Afridi, M. Ilyas, M. Sohail and H. Abid, Development of strawberry jam and its quality evaluation during storage. Pak. J. Biochem. Mol. Biol., 15(1): 23-25, 2012.

[13]. S.B. Manjeshwar, A.R. Shivashankara, R. Haniadka, J. Dsouz and P.B. Harshith, Photochemistry, nutritional and pharmacological properties of Artocarpus heterophyllus Lam (jackfruit): A review, Food Research International, 44 (7): 1800-1811, 2011.

[14]. C.Mondal, R.N.Remme, A.A. Mamun, S. Sultana, M.H. Ali and M.A. Mannan, Product development from jackfruit (Artocarpus heterophyllus) and analysis of nutritional quality of the processed products. Journal of Agriculture and Veterinary Science (IOSR-JAVS), 4: 76-84, 2013.

[15]. P. Naik, K. Snehal, S.V. Joshi, V.S. Dandekar and A.J. Mayekar, Utilization of Jackfruit (Artocarpus heterophyllus L.) Pulp in the Manufacture of Basundi. Trends in Biosciences. 10(20):3913-3915, 2017.

[16]. B. Navez, M. Letard, D. Graselly and M. Jost, Les criteres de qualite de la tomate. Infos-Ctifl. 155: 41-47, 1999.

[17]. S. Nielsen, Food analysis (3rd ed.). New York: Kluwer Academic, 2003.

[18]. O. Prakash, R. Kumar, A. Mishra and R. Gupta, Artocarpus heterophyllus (Jackfruit): An overview. Pharmacognosy Reviews 3:353-358, 2009.

[19]. M. Reinagel, Nutrition Diva's Secrets for a Healthy Diet: What to Eat, What to Avoid, and What to Stop Worrying About (Quick \& Dirty Tips). St. Martin's Griffin; First edition, 2011.

[20]. N.M. Safdar, A. Mumtaz, T. Hameed, N. Siddqui, S. Khalil and M. Amjad, Storage studies of jam prepared from different mango varieties. Pakistan Journal of Nutrition, 11 (7), pp. 555-561, 2012

[21]. E. Sahlin, G.P. Savage and C.E. Lister, Investigation of the antioxidant properties of tomatoes after processing. Journal of Food Composition and Analysis. 17: 635-647, 2004.

[22]. SAS, SAS Users Guide. Statistical Analysis System, 2000 ed. SAS Institute, Inc., Cary, N.C., M.S. Taga, E.E Miller, and D.E. Pratt, 1984. Chia seeds as a source of natural lipid antioxidants. Journal of American oil chemical society, 61: 928-993, 2000.

[23]. V.L. Singleton, R. Orthofer, R.M. Lamuela-Raventós and P. Lester, 1999. Analysis of total phenols and other oxidation substrates and antioxidants by means of Folin-Ciocalteu reagent. Method enzymol., 299:152-178, 1999.

[24]. S.B. Swami, N.J. Thakor, P.M. Haldankar and S.B. Kalse, Jackfruit and Its Many Functional Components as Related to Human Health: A Review. Comprehensive Reviews in Food Science and Food Safety, 11: 565-576, 2012.

[25]. Y.P. Tang, B.L.L. Linda and L.W. Fran, Proximate analysis of Artocarpus odoratissimus (Tarap) in Brunei Darussalam, International Food Research Journal 20 (1):409-415, 2013.

[26]. E.S. Tee and C.L. Lim, Carotenoid Composition and Content of Malaysian Fruits and Vegetables by AOAC and HPLC methods. Food Chemistry, 41: 309-339, 1991

[27]. B. Umesh, J. Shrimant, N. Panaskar and V.A. Bapat, 2010. Evaluation of Antioxidant Capacity and Phenol Content in Jackfruit (Artocarpus heterophyllus Lam.) Fruit Pulp. Plant Foods Hum. Nutr., 65, 99-104, 2010. 